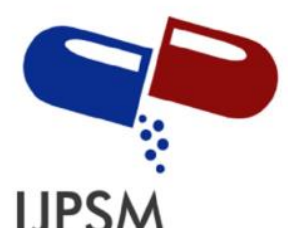

Nessa Nessa et al, Int. Journal of Pharmaceutical Sciences and Medicine (IJPSM), Vol.6 Issue. 9, September- 2021, pg. 17-26

ISSN: 2519-9889

Impact Factor: 3.426

\title{
NEFROPROTECTOR EFFECT OF CORN SILK (Stigma maydis) ETHANOL EXTRACT ON GENTAMICIN INDUCED IN WISTAR RATS
}

\author{
Nessa Nessa ${ }^{1 *}$; Ridho Andriza ${ }^{1}$; Hazli Nurdin ${ }^{1}$; Ridho Asra ${ }^{2}$ \\ 'Faculty of Pharmacy, Perintis University, Padang 25173, West Sumatera, Indonesia \\ ${ }^{2}$ School of Pharmaceutical Science Padang, West Sumatera, Indonesia \\ E-mail address: nessa91nessa@gmail.com \\ DOI: 10.47760/ijpsm.2021.v06i09.003
}

\begin{abstract}
Corn silk (Stigma maydis) is one part of the corn plant that contains useful chemical compounds, including flavonoid compounds. This study aimed to determine the nephroprotective effect of corn silk ethanol extract on male white rats. This type of research is an experimental study, where animals were grouped into 5 groups consisting of the negative control group only given $0.5 \% \mathrm{NaCMC}$ suspension orally, the positive group given gentamicin $80 \mathrm{mg} / \mathrm{kgBW}$ intraperitoneally. the treatment group of corn silk extract doses of 250, 500, and 1000 $\mathrm{mg} / \mathrm{KgBW}$, the group was given an extract suspension orally for 8 days. On the 3rd day of extract administration, gentamicin was administered intraperitoneally 1 hour after administration of the extract until the 8th day extract administration. On the 8th day urine was collected for microscopic examination and on the 9th day blood was taken from the orbital vein of the eye to measure serum creatinine and urea levels, after that the animals were sacrificed and their ratio of kidney weight and histopathology was calculated. gentamicin showed a significant decrease in serum creatinine and urea levels when compared to the positive control group. Histopathological analysis also showed an increase in cell regeneration and the lowest percentage of tubular epithelial cell damage among other doses. Based on the results of the study, it was concluded that there was a nephroprotector effect on the ethanolic extract of corn silk and a variation of the dose of $1000 \mathrm{mg} / \mathrm{KgBW}$ was effective as a nephroprotector.
\end{abstract}

Keywords: Corn silk, ethanol extract, gentamicin, nephroprotector 


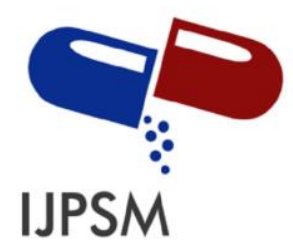

Nessa Nessa et al, Int. Journal of Pharmaceutical Sciences and Medicine (IJPSM), Vol.6 Issue. 9, September- 2021, pg. 17-26

ISSN: 2519-9889

Impact Factor: 3.426

\section{Introduction}

Kidneys are important organs that function to maintain the composition of the blood by preventing the accumulation of waste and controlling fluid balance in the body, maintaining stable levels of electrolytes such as sodium, potassium, and phosphate, and producing hormones and enzymes that help in controlling blood pressure, making red blood cells and keep bones strong [1]. If the kidneys have decreased or are unable to perform these functions, then the kidneys are said to have kidney disorders. Kidney failure is a condition in which the kidneys are damage so that they can no longer carry out their excretory fungtion properly. This condition can lead to accumulation of metablic waste products that cause poisoning in the body. In addition, kidney failure is often followed by various other physiological disorders [2,3]. Gentamicin is also toxic to various organs such as kidneys, liver, lungs, and skin skin because it induces free radicals and oxidative stress [4]. One of the main toxicities of this antibiotic is nephrotoxicity, the observed form of nephrotoxicity is the acute form. Acute nephrotoxicity can occur within a week. It is characterized by the inability to urinate (non oliguria). Gentamicin acute toxicity is believed to arise as a result of its accumulation in lysosomes in the proximal tubule and trigger tubular cell necrosis [5]. The decrease in the glomerular filtration rate (glomerular filtration route) occurs after several days and persists even after gentamicin has been discontinued. Nephrotoxicity in humans can be seen from the results of an increase in creatinine greater than or equal to 0 .

Previous research that corn silk extract has a nephroprotector effect in experimental animals can reduce creatinine in blood serum as a kidney marker and its antioxidant levels can reduce damage to kidney failure [6]. However, studies on the effects of plants are still lacking, so the purpose of this study was to examine the nephroprotector effect of corn silk extract in male white rats and determine the dose variation on the nephroprotector effect in male white rats.

\section{Materials and Methods}

\section{Tools}

rotary evaporator, mortar and pestle, test tube, maceration bottle, measuring cup, beaker, erlenmeyer, spatel, funnel, dropper, stirring rod, experimental animal scale, watch glass, oral probe, gloves, vacutest tube, tools surgery (scissors, tweezers) injection syringe, incubator, drip plate, measuring pipette, tube rack, centrifuge, photometer analyzer, feeding and drinking rat, microscope, oven, fornest, porcelain exchange rate, olympus BX 51 light microscope, Beta 3.1MP camera Sony Exmor CMOS Sensor.

\section{Animal}

Male white rats aged 10-12 weeks, weighing 150-200g, were kept under usual management conditions in animal cages, Pioneer University. Rats were given standard laboratory food and water.

\section{Plant}

Corn silk (Stigma maydis) was taken from the district of 50 cities, Payakumbuh and identified the plants in the herbarium of Andalas University, Department of Biology, Faculty of Mathematics and Natural Sciences, Andalas University, Padang. 


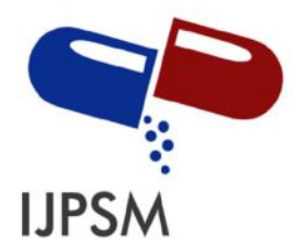

Nessa Nessa et al, Int. Journal of Pharmaceutical Sciences and Medicine (IJPSM), Vol.6 Issue. 9, September- 2021, pg. 17-26

ISSN: 2519-9889

Impact Factor: 3.426

\section{Preparation of extracts}

The sample extract was carried out by means of a fresh sample of corn silk cleaned of impurities by washing with clean water, then drying, then the sample was macerated by putting the sample into a dark colored bottle soaked in $70 \%$ ethanol solvent for 6 hours while stirring occasionally, leaving it for 18 hours. After that it is filtered to get the maserate, the filtering process is repeated at least 1 time with the same solvent and the total volume is half the volume of the solvent in the first filtration. Combine the maserate and then the maserate is evaporated with a rotary evaporator until a thick extract is obtained [7].

\section{Experimental procedure}

After acclimation, the experimental animals were divided into 5 groups, each group consisted of 4 rats, where the extract and gentamicin were induced for 8 days. The experimental animal group consisted of: a negative control group where $0.5 \% \mathrm{NaCMC}$ suspension was given orally, the positive group was given gentamicin $80 \mathrm{mg} / \mathrm{kgBW}$ given intraperitoneally. Corn silk extract treatment group doses of 250,500 , and $1000 \mathrm{mg} / \mathrm{KgBW}$, the group was given the extract orally for 8 days, on the 3rd day the extract was administered intraperitoneally 1 hour after administration of the extract until the 8th day of administration of the extract.

\section{Sample collection}

On the 8th day urine was collected for microscopic examination and on the 9th day blood was collected in the orbital vein of the eye to measure the levels of urea and creatinine as an indicator of kidney damage. Furthermore, the animal was sacrificed and both kidneys were taken for examination of the kidney weight ratio and histopathological examination.

\section{Histopathological examination}

Histopathological examination of the animal's kidney was taken after the animal was sacrificed, this tissue sample was immersed in a $10 \%$ formalin solution and embedded in paraffin wax, cut to a thickness of $4 \mathrm{~mm}$ and stained with hematoxylin and eosin. The tissue is then examined under light microscopy to observe cell damage to the glomerulus and the condition of the tubules.

\section{Data analysis}

Data analysis for this study used one-way ANOVA using the SPSS 23 program. The results of the ANOVA test would be significantly different if statistically obtained $(\mathrm{P}<0.05)$. Data analysis continued with the DUNCAN Distance Follow-up Test.

\section{Results and Discussion}

In this study, an examination of the excretory organs, namely the kidneys, was carried out. Abnormalities in glomerular filtration cause reduced secretion of urea and creatinine, so that the levels of these compounds are high in plasma. Therefore, measurement of urea and creatinine levels was used as an analytical parameter for kidney function. In addition, microscopic observations of the renal histology were carried out to see the changes that occurred in the kidney tissue. 


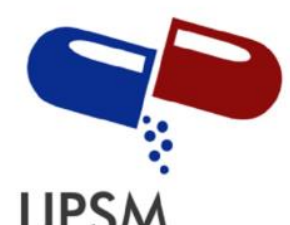

Nessa Nessa et al, Int. Journal of Pharmaceutical Sciences and Medicine (IJPSM), Vol.6 Issue. 9, September- 2021, pg. 17-26

ISSN: 2519-9889

Impact Factor: 3.426

\section{Microscopic examination of urine}

Microscopic measurement of urine is done by examining the content of urine under a microscope. Urine examination showed the following results, in the first group, namely negative control, no crystals were found in the urine sample, in the second group, namely positive control, many triple phosphate crystals were found where these crystals were most commonly found and erythrocytes were also found, this indicates the presence of red blood cells in the urine. In urine, in the extract group at a dose of $250 \mathrm{mg} / \mathrm{kgBW}$ crystals were still found, but not as many as positive controls, at a dose of $500 \mathrm{mg} / \mathrm{kgBW}$ and $1000 \mathrm{mg} / \mathrm{kgBW}$ the crystals had decreased although they could still be seen.

\begin{tabular}{|c|c|c|c|c|c|}
\hline Microscopic & Ex 1 & Ex 2 & Ex. 3 & Ex 4 & Ex 5 \\
\hline Leukocytes (1-5) & 3 & 4 & 3 & 3 & 4 \\
\hline Erythrocytes (0-1) & 0 & 1 & 0 & 0 & 0 \\
\hline Cylinder (+/-) & - & - & - & - & - \\
\hline Epithelium (+/-) & + & + & + & - & - \\
\hline Crystal (+/-) & - & + & + & + & + \\
\hline
\end{tabular}

Table 1. Urine Microscopic Examination

The presence of crystals in the urine may indicate impaired kidney function. In addition, the formation of crystals in the urine also indicates a predisposition, including infection, which can allow disease to occur. The presence of red blood cells (erythrocytes) in the urine describes an abnormal kidney condition, kidney disease in certain and dependent conditions can reduce the glomerular filtration rate. When glomerular function has been damaged, substances measuring $>3-7 \mathrm{~nm}$ that can pass through the glomerulus include proteins and blood cells. 


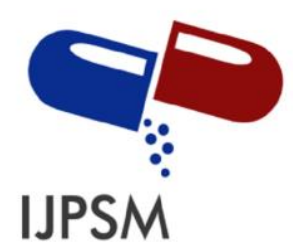

Nessa Nessa et al, Int. Journal of Pharmaceutical Sciences and Medicine (IJPSM), Vol.6 Issue. 9, September- 2021, pg. 17-26

ISSN: 2519-9889

Impact Factor: 3.426

\section{Measurement of creatinine levels}

The measurement of creatinine levels in the blood was done colorimetrically using the Jaffe method. The method was chosen because it is simple, accurate, and fast. The average creatinine levels of male white rats after 8 days of treatment were:

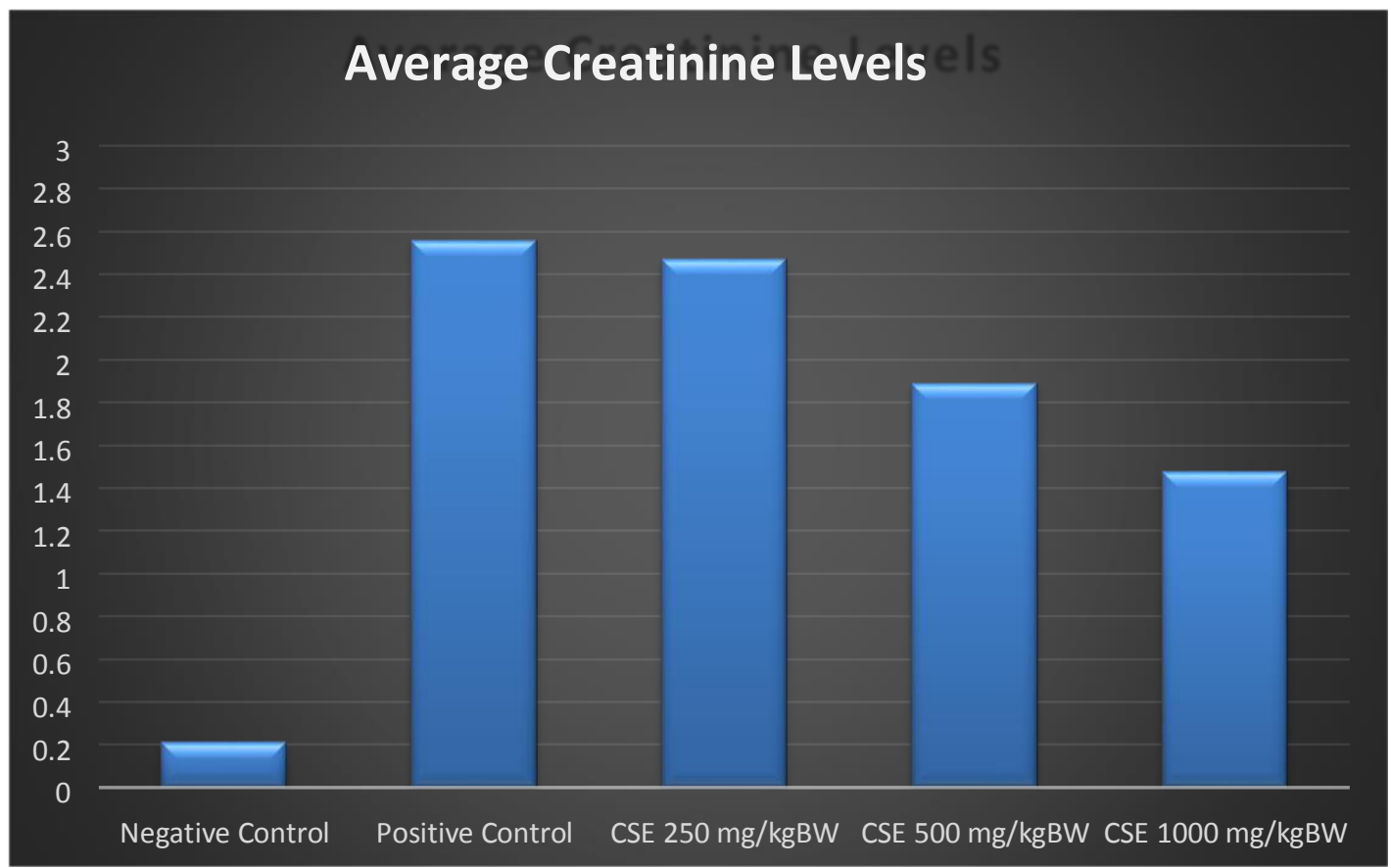

Figure 1. Results Chart of Average Creatinine Levels

The results of the diagram analysis showed that the creatinine levels in the group given the dose of corn silk extract decreased with the increase in the dose of the test preparation given compared to the positive control. This is indicated by the effectiveness of giving corn silk extract.

In the Oneway Anova test, the $\mathrm{p}$ value $=0.000$ in blood serum creatinine, it can be concluded that there was a significant difference in the treatment because the $\mathrm{p}$ value $<0.05$, this indicates that corn silk affects the serum creatinine levels of rats. In Duncan's test to determine the significance of the differences from each treatment group. For creatinine levels, the dose of $250 \mathrm{mg} / \mathrm{KgBW}$ was significantly different from the dose of 500 $\mathrm{mg} / \mathrm{KgBW}$, the dose of $1000 \mathrm{mg} / \mathrm{KgBW}$ was significantly different with the positive and negative control groups. For creatinine levels, the dose of $500 \mathrm{mg} / \mathrm{KgBW}$ was not significantly different from the dose of $1000 \mathrm{mg} / \mathrm{KgBW}$, the dose of $250 \mathrm{mg} / \mathrm{KgBW}$ and the positive control group was not significantly different, but significantly different from the negative control group. 


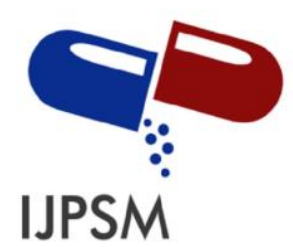

Nessa Nessa et al, Int. Journal of Pharmaceutical Sciences and Medicine (IJPSM), Vol.6 Issue. 9, September- 2021, pg. 17-26

ISSN: 2519-9889

Impact Factor: 3.426

\section{Measurement of urea levels}

Measurement of urea levels in the blood was done colorimetrically using the Jaffe method. The method was chosen because it is simple, accurate, and fast. The average urea levels of male white rats after 8 days of treatment were:

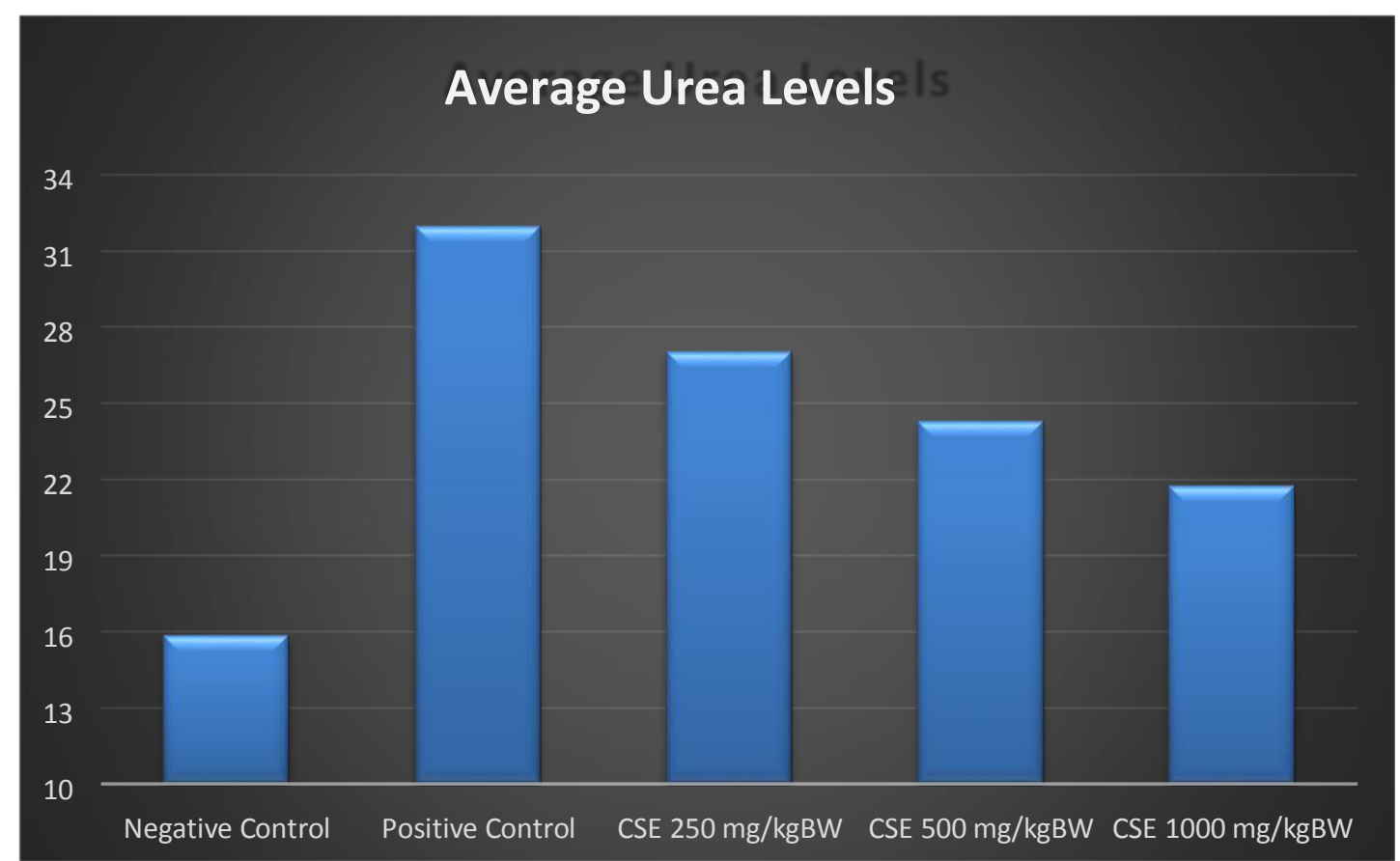

Figure 2. Results Chart of Average Urea levels

The results of the diagram analysis showed that the urea levels in the group given corn silk extract decreased significantly when compared to the positive control. In the positive control, the urea value is above normal, this shows that gentamicin can interfere with kidney function, if it is seen that giving a dose of $1000 \mathrm{mg} / \mathrm{kgBW}$ is the most effective in providing a protective effect on the kidneys of experimental animals. In the Oneway Anova test, the value of $p=0.000$ in urea was obtained, it can be concluded that in the treatment there was a significant difference because the $\mathrm{p}$ value $<0.05$, this indicates that corn silk extract affects the urea levels of rats. In Duncan's test to determine the significance of each treatment group. For the average urea levels, negative control, positive control, dose of $250 \mathrm{mg} / \mathrm{KgBW}$, dose of $500 \mathrm{mg} / \mathrm{KgBW}$ and dose of $1000 \mathrm{mg} / \mathrm{KgBW}$ were all significantly different respectively. 


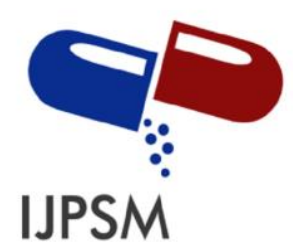

Nessa Nessa et al, Int. Journal of Pharmaceutical Sciences and Medicine (IJPSM), Vol.6 Issue. 9, September- 2021, pg. 17-26

ISSN: 2519-9889

Impact Factor: 3.426

\section{Animal organ weight ratio}

The ratio of the weight of the kidney organ was calculated by weighing the weight of the rat before being sacrificed, then divided by the weight of the kidney organ, the result was multiplied by one hundred percent. The calculation of the kidney ratio was carried out to determine whether there was an effect of the treatment of the group on the organ mass of the rat. The percentage ratio of kidney for 8 days is

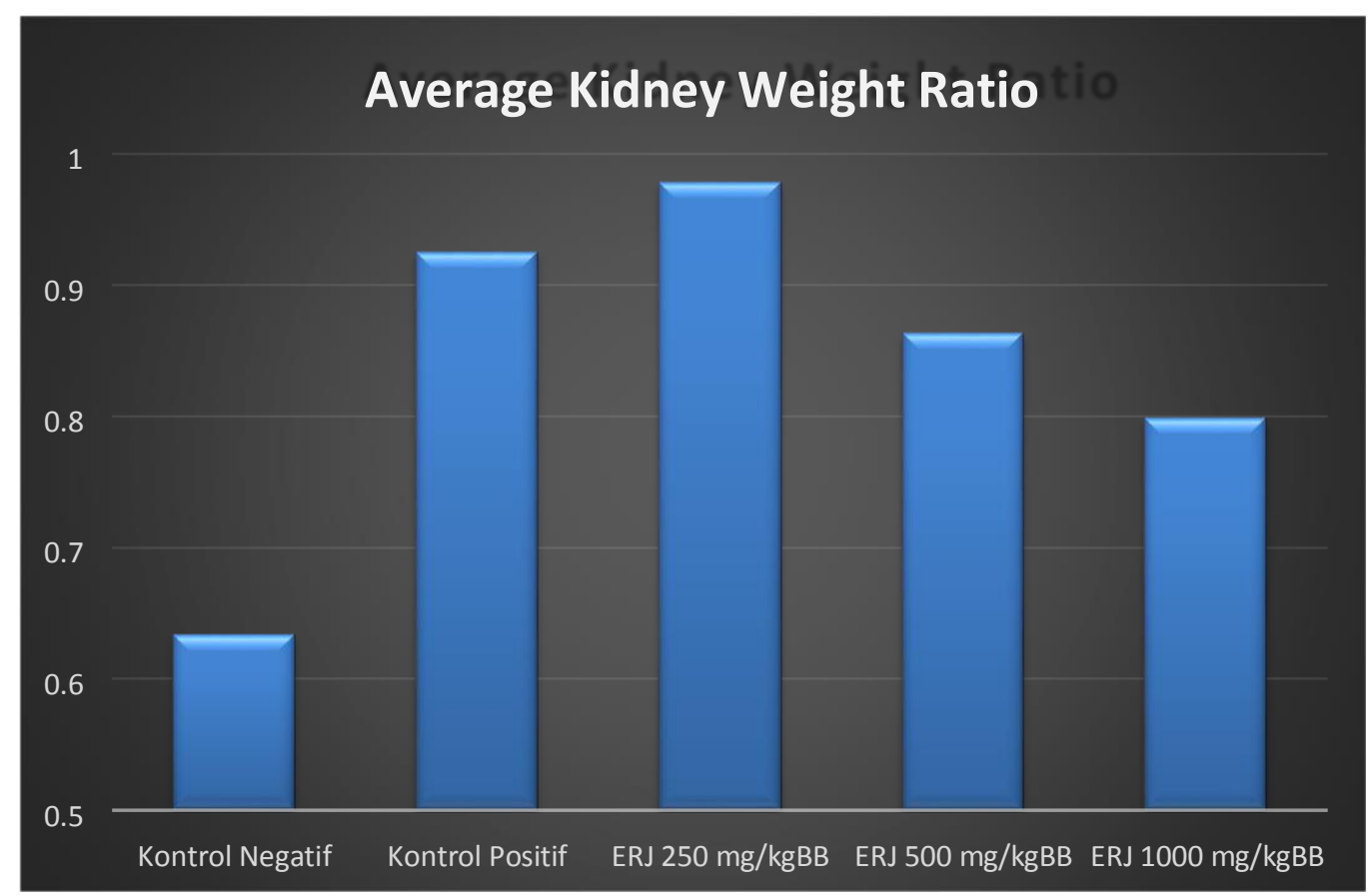

Figure 3. Ratio Percentage Results Average Kidney Weight Ratio

From the results of the ratio of kidney organs, it can be concluded that a good kidney weight is a kidney weight that is close to the weight value of a negative control kidney. Where the negative control is used as a reference for normal weight in this study. Visible effective dose is at a dose of $1000 \mathrm{mg} / \mathrm{kgBW}$.

In the Oneway Anova test, $\mathrm{p}$ value $=0.009$ in rat kidney ratio, it can be concluded that in the treatment there is a significant difference because $\mathrm{p}$ value $<0.05$, this indicates that corn silk extract affects the percentage of rat kidney organ ratio. In Duncan's test to determine the significance of the differences from each treatment group. For the percentage of kidney weight ratio, the dose of $250 \mathrm{mg} / \mathrm{KgBW}$ was significantly different from the dose of 500 $\mathrm{mg} / \mathrm{KgBW}$ and $1000 \mathrm{mg} / \mathrm{KgBW}$. The dose of $500 \mathrm{mg} / \mathrm{KgBW}$ was not significantly different from the dose of 1000 $\mathrm{mg} / \mathrm{KgBW}$, but significantly different from the negative control, the positive control group was not significantly different from the dose of $500 \mathrm{mg} / \mathrm{KgBW}$ but significantly different from the negative control. 


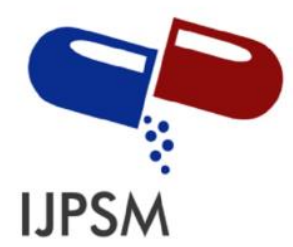

Nessa Nessa et al, Int. Journal of Pharmaceutical Sciences and Medicine (IJPSM), Vol.6 Issue. 9, September- 2021, pg. 17-26

ISSN: 2519-9889

Impact Factor: 3.426

\section{Histopathological Examination}

In histopathological testing, there are differences in the histopathological picture of experimental animal kidney tissue between groups in the research sample,

such as damage to tubular epithelial cells, tubular epithelial damage characterized by cell degeneration seen with cell necrosis marked by cell lysis (cells without a nucleus) and edema in the tubules.

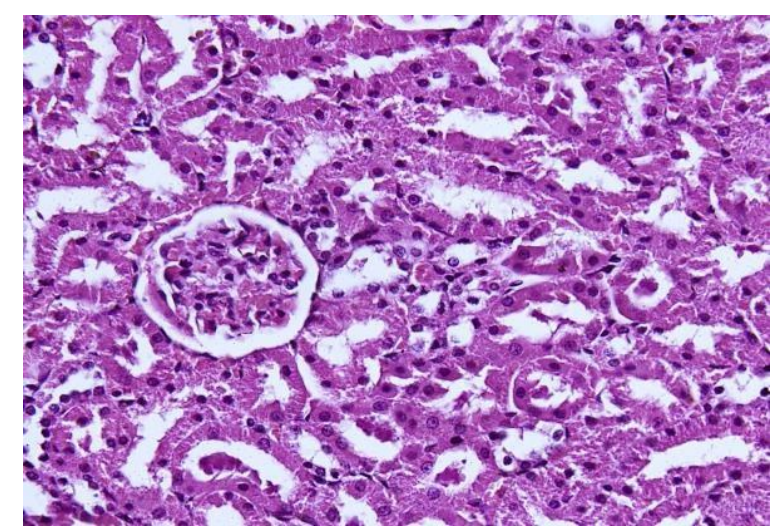

Figure 4. Histology of kidney tissue in the experimental control group was negative, showing the renal cortex with tubules $(\mathrm{T})$ and glomeruli $(\mathrm{G})$. In the negative control group, the renal parenchyma appeared with normal tubuli and glomeruli.

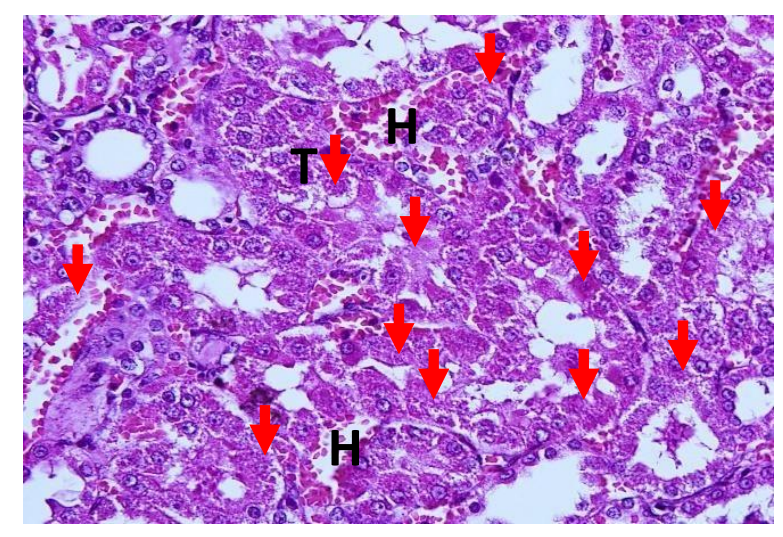

Figure 5. Histology of kidney tissue of experimental animals in the positive control group showed renal cortex with tubules (T) and glomeruli (G). Gentamicyn induction treatment showed marked parenchymal damage, tubules with degeneration and cell necrosis, dilated blood vessels, and bleeding

From the results of the percentage of tubular and glomerular damage obtained, it can be seen that: the lower proportion of cells that were damaged on administration of corn silk compared to positive control, the extract gave the impression of a protective effect on kidney damage by toxic substances such as gentamicin. This effect can be 


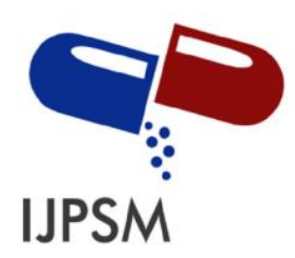

Nessa Nessa et al, Int. Journal of Pharmaceutical Sciences and Medicine (IJPSM), Vol.6 Issue. 9, September- 2021, pg. 17-26

ISSN: 2519-9889

Impact Factor: 3.426

in the form of a direct antioxidant effect, the active substance in corn silk extract which works to prevent the effects of gentamicin radicals directly. but this effect can also be an indirect effect by improving the resistance of the epithelium to toxic substances.

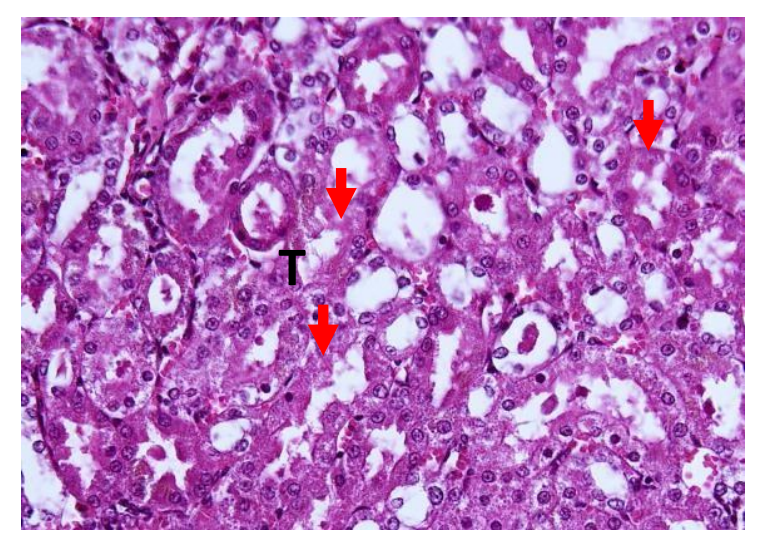

Figure 6.Histology of kidney tissue in experimental control group treated with a dose of 1000mg of stigma maydis showed the renal cortex with tubules (T), and glomeruli $(\mathrm{G})$. Treatment with induction of gentamicin and corn silk extract $1000 \mathrm{mg} / \mathrm{kgBW}$ showed marked parenchymal damage, tubules with degeneration and cell necrosis, but kidney damage was lower than positive controls with other doses of stigma maydis. The administration of stigma maydis extract showed an improvement in the histological morphology of the renal parenchyma, reduced the number of necrotic cells, and reduced areas of bleeding and inflammation.

At a dose of $1000 \mathrm{mg} / \mathrm{kgBW}$, the percentage of tubular and glomerular damage was the lowest compared to the other dose extract groups, meaning that this dose was the most effective because it prevented the tubuli and glomerulus of the kidney from being more severely damaged.

From the average value of creatinine and urea in rats and in the percentage of kidney damage where at the lowest dose of $1000 \mathrm{mg} / \mathrm{KgBW}$, kidney damage occurred compared to $250 \mathrm{mg} / \mathrm{kgBW}$ and $500 \mathrm{mg} / \mathrm{kgBW}$, this was due to the nephroprotective effect of hair extract because it contains compounds flavonoids, suspected flavonoids as compounds that prevent or improve kidney function. The flavonoids contained in plants are thought to act as extracellular antioxidants by inhibiting the enzymes responsible to produce suproxide radicals $\left(02_{-}^{-}\right)$xanthine oxidase and protein kinase C. [8]. Flavonoids also prevent oxidative stress in the kidneys by increasing the antioxidant activity of glutathione $\mathrm{S}$ transferase (GSH), increasing GSH synthesis and trapping ROS Dierectly by donating $\mathrm{H}$ atoms from the hydroxyl group $(\mathrm{OH})$ to free radicals so that the free radical compounds formed are not reactive and Meanwhile, flavonoid compounds that become donors turn into radical flavonoid compounds that will bind to other flavonoid radicals into an unreactive form [9]. So a dose of $1000 \mathrm{mg} / \mathrm{kgBW}$ is most effectives as nephroprotective. 


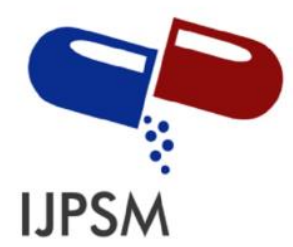

Nessa Nessa et al, Int. Journal of Pharmaceutical Sciences and Medicine (IJPSM), Vol.6 Issue. 9, September- 2021, pg. 17-26

ISSN: 2519-9889

Impact Factor: 3.426

\section{Conclusion}

From the result of this study, it can be conclude that the ethanol extract of corn silk has nephroprotector effect on the kidneys of male white rats seen from microscopic urine, creatinine and urea levels, ratio of kidney weight of rats and kidney histopathology of white rats. The dose of $1000 \mathrm{mh} / \mathrm{kgBW}$ is the most effective dose for nephroprotector effect.

\section{References}

[1]. Kemenkes,. InfoDATIN. Kidney Disiase Situation. 2017.

[2]. Thye, W.K., 1998. Clinical Nephrology. World Scientific Publishing Co. Pvt. Ltd., Singapore, pp: 274, 285.

[3]. Zdanowicz, M.Z.M., 2003. Essentials of Pathophysiology of Pharmacy: An Integrated Aproach CRG Press/Taylor and Francis Group, USA., ISBN-13: 9781 587160363, Pages: 228.

[4]. Khan, M.R., Badar I. \& Siddiquah A, 2011. Prevention of hepatorenal toxicity with Sonchus asper in gentamicin treated rats, BMC Complementary and Alternative Medicine, 11:113.

[5]. Myo KK, dan David PN. 2007. Antimicrobial Pharmacodynamics in Theory and Clinical Practice. Editor: Charles Nightingale, Paul Ambrose, George Drusano, dan Takeo Murakawa. Second Edition. New York: Informa Healthcare: Hal. 159.

[6]. Faruk H, Rafi A. M, Zainab A, Thulfuqar A. M, 2012. Nephroprotective effect of Corn Silk extract on oxalic acid-induced nephrocalcinosis in rabbit model. The Journal of Intercultural Ethnopharmacology.

[7]. Depkes RI. 2000. General standard Parameters of Medicinal Plant Extract. Jakarta: Directorate of Traditional Medicine Supervision.

[8]. Pieta, P,G. 2000. Flavonoids as Antioxidants. Journal Of Natural Products (63): 1034-1046.

[9]. Dahal, A., dan Sirisha, M. (2015). Flavonoids In Kidney Protection. Review Article. World Journal Of Pharmacy And Pharmaceutical Science. 4: hal.362-365. 